\title{
The Role of DFIs in Industrial Growth and Transformation: Why the East Asian Countries Succeeded and Pakistan Did Not
}

\section{Shakil Faruqi ${ }^{*}$}

\begin{abstract}
In this paper we explore how development finance institutions (DFIs) helped to promote industrial growth with active role of public sector in emerging market economies - Korea, China, India, Malaysia, Brazil, Mexico, Turkey. The DFIs provided long-term credit financing which led to structural transformation of their economies. These countries have succeeded in spectacular fashion at this transformation over the past four decades but Pakistan did not; why?

There has been an endless debate concerning the role of the public sector vis-à-vis the private sector in promoting economic growth and it continues in the present. I begin by asserting that historically public sector has been in the forefront in starting and sustaining economic growth. This not a leap of faith, rather this has been the experience of most emerging economies. They have gone through reforms, liberalization and structural adjustment, ushering in marketbased policy regime and opening up foreign trade and capital flows.

Within this framework, the role of DFIs has been exemplary, an assessment I reach based on published researched evidence but from field experience in the East Asian economies during 1980s, where newly established industries, in part supported by World Bank (WB) funded DFI lending, nurtured industrial transformation. When the industries of advanced countries began leaving in droves, pressure mounted to end industrial financing.

It is a fascinating saga. We need to discover why Pakistan did not succeed in achieving the same industrial transformation the occurred in emerging economies. This failure occurred in spite of similar types of DFI lending over a long period and an almost manic devotion of government to the role of public sector. Reforms and privatization is still going on; but industrial transformation remains as elusive as ever.
\end{abstract}

Keywords: Industrial growth, development finance institutions, economic development, Pakistan.

JEL classification: O10.

${ }^{*}$ Professor, Faculty of Business Administration, Lahore School of Economics 


\section{Introduction}

Development finance institutions (DFIs) have played a salutary role in economic development - mainly through industrialization in the early stages of growth - in most developing countries, including Pakistan. These were state-owned and funded institutions, many of which were established with the help of the World Bank, which extended long-term foreign currency loans or standby credit lines with a government guarantee. The DFIs, in turn, began on-lending these funds on a retail basis mostly to state enterprises as forex loans to set up new industrial units and "jumpstart development by the bootstraps" - an expression much in vogue then.

The DFIs' main function was to provide industrial development credit finance and some agricultural finance for farm machinery, fertilizers and chemicals. This credit financing was designed for project-based investment carried out under carefully set guidelines to ensure the completion of the planned industrial units, initially in the public sector and eventually in the private sector. The latter grew vigorously during the 1970s and after, through into the 1990s. The long-term credit financing extended by the DFIs was used to cover the forex costs of plant machinery and equipment in public sector industrial units. The on-lending followed an elaborate protocol that specified rules and regulations for the use of borrowed funds, with strict oversight by the DFIs and the World Bank on the viability of the industrial projects being financed.

This financing mechanism served very well because it maintained its fidelity. The DFIs performed well and were instrumental in jumpstarting Pakistan's fledgling industrial sector. Thus, two systems existed in parallel: (i) the largely private commercial banking system, which expanded considerably as new banks (such as UBL) opened up; and (ii) the newly established or reorganized DFI system. The perception that banking was merely petty coin tending (banyagiri) - a derisive term for the centuries-old mercantilist tradition in the Indian Subcontinent began to shift as DFIs fostered the growth of new businesses, industries, and mercantile traditions, and helped a new class of entrepreneurs evolve. In the start-up phase, this was the preferred mechanism for jumpstarting industrial development in the public sector. Later, as the nascent private sector emerged, the DFIs began lending to private industrial units sponsored by the public sector. The on-lending was often subsidized to enable the establishment of new units and operations. 
The government's elaborate foreign trade and investment policy and incentive regime was designed to protect and nurture new industries, mostly through import substitution. All this came to be accepted as infant industry development supported by the DFIs to meet the needs of targeted industries or sectors. In parallel, the government invested heavily in supporting infrastructure to enable the start-up of new industries. This included building industrial sites and services, and was made possible through generous foreign assistance from bilateral and multilateral institutions. However, what remained lacking - barring among the small Muslim business community that had migrated from India in 1947 - were general pro-business attitudes and entrepreneurship.

\section{Early Industrialization in Pakistan}

This section provides an overview of the role of DFIs in Pakistan's initial stages of industrialization from the 1950s to the 1970s.

\subsection{DFIs and Early Industrialization}

From the mid-1950s through the 1970s, the role of DFIs and support for public sector industrialization were seen as key to the country's development. The government focused on establishing basic consumer good industries, textiles, and cement, and on mechanizing agriculture and initiating basic agro-industries (all geared toward import substitution). Pakistan's five-year plans and documents published by research groups such as the Harvard Advisory Group indicate that the development of export industries was not on the horizon, nor was much attention paid to comparative costs and competitiveness.

In line with this strategy, an import substitution-oriented policy and incentive regime evolved, supplemented by controls, approvals, licensing, and a tightly controlled foreign trade regime. Fixed exchange rates and an overvalued domestic currency gave import substitution a significant advantage over export-led industries. Initially, this strategy succeeded. From the mid-1950s through the mid-1960s, a large number of industries were set up in Pakistan, including textiles, sugar, cement, fertilizer, and petrochemicals. Some private banks and insurance companies were also established. In the wake of this success, Pakistan was touted as a successful developing country and a role model.

This led to the phenomenal growth of reputable "business houses" such as the Adamjees, Saigols, Ispahanis, and Dawoods, among 
others, most of which were active in West Pakistan because the government had not demarcated group-linked ownership and the resulting wealth concentration. These houses established industrial and business units in East Pakistan, but not on the same scale as in West Pakistan. The DFIs were willing to lend to newly minted industrial and business houses because their business model was characterized by transparency, accredited accountability, proven creditworthiness, profitability, sound management and solid performance all around.

The feverish pace of group-linked private investment and the rapid establishment of new industries, businesses, banks, and insurance companies reached unprecedented levels. This business model operated in sync with the much-heralded strategy of economic growth Pakistan had adopted. Their success, however, led to criticism of runaway accumulation and large concentrations of wealth among the 22 largest mercantile families. Following the war of 1965, a combination of factors political upheaval, the growing disparities between East and West Pakistan, the elections of 1970, and West Pakistan's refusal to accept the legitimacy of the popular verdict - led to a civil war, resulting in the truncation of Pakistan.

\subsection{Truncation and Nationalization in the 1970s}

After 1971, the DFIs lost nearly all their assets in former East Pakistan, while the client companies that survived in West Pakistan suffered major losses. Much of their asset base simply evaporated in the chaos. Additionally, the new Government of Pakistan embarked on a nationalization program in the name of socialism, wiping out private corporate businesses, industries and commercial units, and sparing only small retail traders, artisans and small machine repair workshops. The Mao cap in vogue in those days was meant as a symbol of Chinese-style socialism, but the ruling party's intelligentsia prescribed a Fabian variety of socialism. The majority were at a loss to understand what they intended and were concerned with guarding their own interests.

All key industries, businesses, and financial institutions were nationalized, including the assets of the group that became known as the "22 families." The financial structure that had sustained commerce was largely dismembered and much of the banking system became a vehicle of resource transfer from the public to the state. The government ended up playing multiple roles - industry owner, financier, lender, and borrower - managed by senior bureaucrats without any experience of 
running a business. The state-owned DFIs, however, were not closed down. They retained their role as credit providers, but ended up financing state-owned enterprises with disastrous consequences.

India followed a similar path of nationalization, but at a less frenzied pace. Its government gave the private sector space to continue operating and helped as far as it could. India nationalized its banking system at the same time as Pakistan (an uncanny coincidence), but refrained from taking over the financial system and did not touch the business houses, the seths and conglomerates, or mercantile houses such as the Tatas and the Birlas.

Instead, India continued to nurture businesses, both large and small, and pursued import substitution industries in the private sector behind an elaborate protective wall. It did not succumb to pressure to open up its markets en masse, nor did it allow foreign ownership of industrial and commercial units, although it did encourage foreign capital inflows on its own terms. The "license raj" was heavy-handed, no doubt: growth rates were anemic, derisively called the "Hindu" rate of growth, but the drive for industrialization was broadened and sustained. India's DFIs continued functioning and did not suffer catastrophic losses in industrial or SME financing. The foundations of industrial transformation continued to gain depth and strength, which subsequently paid rich dividends in the 1990s and beyond to propel the Indian economy towards the spectacular growth it has witnessed in the last couple of decades.

\section{The East Asian Countries}

Having examined the early role of DFIs in Pakistan, this section turns to the strategies adopted by many East Asian countries.

\subsection{The Early Years}

Korea, Taiwan and Malaysia, followed by Thailand, Indonesia and the Philippines, pursued a similar trajectory of state-sponsored and protected industrialization in the early stages of development, financed by DFIs (most of which were funded by the World Bank, barring Taiwan). China joined later in the early 1980s. However, the industrial growth model these countries adopted was very different from that of Pakistan. From the start, it was outward-oriented, focusing on export-led growth and thus on cost-efficiency and competitiveness overseas, following the lead of Japan and, subsequently, Korea and Taiwan. Arguably, Korea and Taiwan 
are special cases of preferred sponsorship by the US, while Hong Kong and Singapore are city-states and so forth. Nonetheless, many East Asian countries were able to emulate their success.

These countries promoted their industry under a foreign trade regime with a sophisticated protective umbrella so as not to invite outright retaliation from advanced countries. The key difference was that their governments did not become involved in owning and running industrial enterprises as they did in Pakistan in the 1970s. The East Asian bloc did not repudiate local entrepreneurship; instead, these countries rallied to provide local business full support under investment packages, including state-guaranteed foreign credit financing, investment incentives, and access to facilities. They also competed with each other to furnish incentives with a view to attracting foreign investment.

Simultaneously, the East Asian countries invested heavily in technical education to nurture the growth of a well-trained, disciplined local labor force. This was another key difference vis-à-vis Pakistan, the impact of which emerged later through the acquisition of new technology and licensed patents from Japanese companies in the initial rounds. Subsequently, European and US companies launched their own operations in East Asia such that the consumer goods produced were exported to their host countries. By the late 1970s, this mode of industrialization had succeeded, enabling their industrial 'infants' to grow up. China joined this club later in the early 1980s.

As these new industries gained a foothold, the East Asian governments began to shed their protective curtain. They charted out new foreign trade regimes, provided various incentives for export, and established export-processing zones (EPZs), often with DFI funding backed by World Bank credit. The EPZs were cordoned off from the local economy to avoid customs duties with very low excise taxes for direct exports. Initially, they comprised assembly line operations established as subsidiaries of leading brands based in Japan, the US, and Europe.

This was the beginning of the relocation of what later came to be known as "footloose" industries, whereby advanced countries were keen to identify those willing to offer lucrative incentive packages to foreign direct investment (FDI). I supervised a number of studies on the investment incentives of Thailand and Malaysia in the early 1980s. At the time, the East Asian DFIs were at the center of the industrial transformation I observed at close quarters in 1980-86. Once the assembly 
line operations became successful in export markets, they spawned supply chain industries (mostly SME units) based on local manufacturing content. By the early 1980s, this transformation had taken root in emerging market economies, but not in Pakistan.

Prior to China's entry on the scene, once the infant industries of East Asia had matured, they began to export light manufactures such as textiles and garments, household consumer goods, light hand-tools and electronic goods to the US and Western Europe at substantially lower costs and without compromising on the quality of exports. Earlier, Japanese-manufactured exports of high-end electronic goods such as TV and VCR sets had wiped out RCA and Motorola TVs and VCRs in the US and Phillips in Europe. Subsequently, the same Japanese products were being manufactured in East Asian countries at lower cost and exported under the same brand name at even lower prices. This was the beginning; the avalanche of "cheap exports" was to come later from the East Asian countries, in an ironic twist replacing "made-in-Japan" exports.

\subsection{Enter China}

In 1981, when China opened up and joined international financial institutions (IFIs) such as the World Bank and International Monetary Fund (IMF), this enabled it to obtain foreign currency credit to modernize its economy and industrial base. The first loan, a line of long-term credit from the World Bank, was made to the China Investment Bank (CIB), which had been established with the World Bank's help. Within a year, the CIB had availed three loans and continued to borrow heavily for the industrial sector. Meanwhile, China set up other DFIs to finance infrastructure managed by various state-owned enterprises. Client companies followed a transparent business model; their project performance was prompt and the on-lending of Chinese DFIs to mostly state-owned enterprises was a resounding success. Although privately owned businesses had emerged, private industrial units had not.

I saw these disbursements at close quarters, often signing for disbursement requests in an acting capacity every day, which comprised a stream of payments from various World Bank lines of credit extended to the East Asian DFIs. Almost all such disbursements were for industrial machinery being imported from advanced countries. In the early 1980s, this type of industrial financing laid the foundation for modern Chinese industry. Most of it was for import substitution; exports came later when 
the footloose industries of advanced countries began to establish manufacturing units with a heavy inflow of FDI.

The transformation of Chinese industry had begun in earnest, initially with industrial finance channeled through its DFIs, but industrial financing alone could not have achieved this transformation. The key ingredients were the entrepreneurship of the Chinese diaspora and the technological transfer that followed in the footsteps of Singapore and Taiwan. China invested heavily in technical education and training, and succeeded - reminiscent of Japan's achievement in acquiring and internalizing technology in the years before the Second World War.

The spectacular transformation of China's industrial sector over the last three decades was unprecedented. The frontline manufacturing of highend consumer brands destined for European and US markets was taken over by industries established by these corporations in China. Moreover, sophisticated high-tech IT equipment and machine tools were licensed to manufacturing units relocated to China for assembly operations and subsequently for production and export back to the US and Europe.

\subsection{Foreign Direct Investment}

A key element of this transformation was the FDI being channeled to the East Asian countries, including China. These inflows began slowly in the mid-1970s and picked up pace during the 1980s as East Asia opened up its capital accounts. Initially, the liberalization was intended for capital inflows with guaranteed repatriation, while strictly controlling outflows except as a selective quid pro quo, item by item, for the industrial units receiving FDI. Unlike Pakistan's case, which involved a free-for-all in reverse sequence during its reforms in the early 1990s, FDI inflows to East Asia were pegged to the establishment of new plants and industries aimed at exporting back to the countries of FDI origin rather than domestic markets.

More importantly, FDI inflows financed new industries bundled together with the transfer of new technology embedded in assembly lines and production units. This required training the local labor force to operate and maintain the new plants - a linkage that extended beyond the financial side of capital inflows. Thus, FDI was not merely a wave of financial entries in the capital account of the balance of payments. Instead, it was a process that helped transform the host economies into modern industrial states. 


\section{DFIs in Pakistan: The Pre-Reform Years}

While the East Asian economies surged ahead, their DFIs playing a central role, Pakistan's DFIs (or what was left of them after 1971) receded into the background, coping with the losses they had incurred as a result of financing loss-making public sector enterprises (PSEs). Gone was the dynamism of private entrepreneurship among import substitution-type industries, in which poor management and overstaffing associated with political patronage and powerful labor unions had led to large losses. The government, as owner, was obliged not only to subsidize their operations, but also to replenish their equity base. The burden of a large fiscal deficit left the state with no option but to close down such enterprises or continue financial support.

Periodically, the government would replenish the equity of defunct PSEs as best as it could, sustaining their loan write-offs through special budget dispensations. The PSEs managed to survive as long as they could on government support (which they garnered through political patronage) or lingered on during the tumultuous days of nationalization until reforms, structural adjustment, and privatization were introduced in the early 1990s.

By the mid-1980s, the financial position of the DFIs' clients had crumbled beyond rescue. The World Bank shut down its outflows as it became clear the DFIs were insolvent, burdened by nonperforming loans (NPLs), euphemistically known as "sick" loans as though some manner of inoculation would cure large and influential willful defaulters. Pakistani DFIs were not alone in this situation. Some DFIs in Indonesia, Malaysia, the Philippines and Latin America also suffered from the same malaise. Although some governments had employed interest rate subsidies via DFI lending - hoping that their clients, the infant industries, would mature - this did not resolve the problem of financial mismanagement. They did not grow into competitive, financially strong industries capable of withstanding the onslaught of foreign competitors with the demise of the quota system under WTO agreements.

Undaunted, however, the Pakistan government established a new DFI, Banker's Equity Ltd, in the early 1980s to provide long-term credit to restart private sector industries and businesses in the midst of nationalized, financially ailing giants. Their business model was predatory from the start and bereft of entrepreneurship: private sector clients would put forward a minimal amount of equity to set up a new 
industrial unit (mostly for import substitution business) under heavy protection, tax holidays, subsidized infrastructure and financing, and overvalued exchange rates - the same industrialization formula that had prevailed decades earlier.

Having garnered this support, they would borrow to the hilt from the DFIs or nationalized banks, thereafter pulling out their equity from the business. If the venture failed, as it often did, they would declare insolvency and use their clout to arrange for a loan write-off - they usually succeeded. The state ended up being the ultimate loser in this kind of DFI-funded private sector industrialization in the 1980s. It is little wonder that the public sector came under heavy criticism from all quarters, while these businessmen went on to become new billionaires.

\section{East Asian Exports: The Aftermath}

In stark contrast to this private business model in Pakistan was that employed by East Asian entrepreneurs who were busy setting up industries based on the Japanese pattern. They would obtain industrial licenses and knowhow from reputable Japanese firms - thus ensuring technology transfer, preferably with some investment by the parent group - and set up industrial units using either the supplier's credit or DFI funding through access to forex lines of credit obtained from the World Bank. Their governments would (i) design competitive investment incentive packages to attract foreign investment, (ii) provide a superb business-friendly environment, (iii) install the requisite infrastructure, (iv) train their own labor force, and (v) educate engineers and executives to launch business operations. This model succeeded for all to see.

These were the modest beginnings of the giants of today: Samsung, LG, Kia and many others in Korea; US- or European-patented high-tech IT products partly manufactured and assembled in the EPZs of Malaysia or China; and brand name high-value items from India and other East Asian or Latin American companies. These new corporate businesses grew rapidly. In short, the East Asian countries, together with successful emerging market economies, underwent a structural transformation from subsistence agro-rural economies to modern industrial giants.

Despite some failures, the East Asian and Indian industries largely succeeded in penetrating foreign markets. Thus began the onslaught of cheap exports to advanced countries as far back as the late 1970s. This gathered momentum during the early 1980s to the point where not only 
ordinary consumer goods, but also sophisticated high-value "white goods" for the housing and automobile industries began to feel the heat of competition from imports. By the late 1980s, the emerging economies were on the frontlines and had taken over much of foreign trade, accumulating trade surpluses and massive forex reserves.

The exports of newly industrialized countries created uproar among importing countries. Their industries could sense plant closure and unemployment because they could not withstand the competition. Often, companies would demand extreme measures, asking for a ban on canned fruits and seafood imports, for example. They sued their governments for protection, especially in the US, claiming that foreign exporters were engaging in unfair trade, supported by governmentguaranteed, subsidized financing channeled through DFIs and stateowned banks. The larger European and US consumer goods industries were especially vociferous because cheap imports threatened their existence, creating rusting belts in many industrial cities.

A good part of this ire was aimed at the World Bank, which was lending substantial amounts of long-term industrial finance as lines of credit to DFIs not only in Asia, but also in Latin America, helping many countries create an industrial base that eventually wiped out a good part of the consumer goods industries in advanced countries. When some of these countries, such as Korea and Taiwan, began to export light machine tools, followed by heavy electrical tools (such as lathe machines), this caused panic in the US and created pressure on the World Bank to stop lending for industrial growth. The World Bank shut down its Industrial Finance Department in 1981, but allowed its regional offices to continue DFI lending, including in East Asia - although only to those DFIs that showed a healthy financial performance record. No interest rate subsidies or state support was offered to the new exporters.

The campaign to cut off credit lines was even more powerful in the case of World Bank-financed large industrial projects. Earlier on, the World Bank's industry department had helped set up integrated steel mills, large machinery plants, refineries, and petrochemical plants using the same formula of heavy public sector investment and ownership, state patronage in the form of subsidized infrastructure and energy supplies, and grants or subsidized lending in the classic mode of early-stage import substitution. Once these units became strong and competitive enough, their exports began affecting large establishments in advanced countries those led by big steel and big oil in the US and Europe - and their 
financiers, the multinational banks. They mounted a concerted campaign against the World Bank financing of industries, pressuring it to shut down these operations.

In the first round, the World Bank pared down lending for large industrial projects. By the late 1970s, its industry department had been reduced to launching studies of effective protection or industrial advisories, conflicting with the industrial development strategies being pursued by emerging countries. Eventually, both the industry and energy project departments were shut down in the early 1980s. In their place came an emphasis on poverty alleviation, good governance, and cash lending for reforms that suited both the client state and the World Bank. Recently, however, the World Bank and Asian Development Bank have resumed lending for large energy projects on a case-by-case basis, keeping independent power producers' interests ahead.

Overall, this sea change forced a massive retreat on the public sector's part from playing a proactive role to a supportive role, subsumed by the leadership of the private sector. In advanced countries, a paradigm shift reshaped the landscape of industrialization. The slogan was that markets were superior, better organized, and more efficient than the public sector. In short, governments should cease the business of promoting development or providing safety nets to public and allied industries both in advanced and developing countries.

This coincided with the rise of conservative governments in the US and UK under the leadership of Regan and Thatcher, which began a crusade against public sector involvement in promoting economic development, following the Chicago School view that markets could do better than the public sector, and that governments played an intrusive rather than constructive role. They argued that this role should be substantially pared down because it obstructed private sector initiatives or sought to compete with the private sector on turf funded and maintained by the government.

This Friedman-esque market mantra spread rapidly to other advanced countries, percolating down to developing countries through overhauled financial aid and assistance. The need to revamp policy and incentive regimes, shift public sector ownership through privatization, embark on structural adjustment programs, and implement economic and financial reforms to remove financial repression became a battle-cry that was lauded by leading economists, opinion makers, and specialists. 
In the case of the financial system in general and DFIs in particular, the argument was that the existing regulatory regime promoted financial repression and that the given interest rate subsidized and layered a system of directed credit, forcing banks, DFIs, and other financial institutions to continue supporting enterprises which otherwise should have been closed down long ago. In some countries, the financial distortions embedded in credit allocation were so acute that they had stymied potential growth. In principle, there is no quarrel with this viewpoint, but in practice, the system of layered credit allocations was used effectively by India and the East Asian countries to achieve industrial growth.

\section{Reforms in the 1990s and mid-2000s}

The sweeping economic and financial reforms undertaken during the 1990s ushered in structural adjustment, restructuring and privatization, and revamped policy and incentive regimes, which completely transformed most economies, including Pakistan.

\subsection{Role of Public Sector Versus Private Sector}

In the wake of such reforms, there occurred several financial crises. It took the global financial crisis of 2008 to drill in the realization that the market mantra was flawed. That is, markets are not perfect; markets are neither self-regulatory nor self-correcting; markets are notoriously unpredictable since they are manipulated by insiders; markets cannot be ordered to behave; and market operations are laced with moral hazard owing to regulatory loopholes, and need to be reined in for the public good. This topic is, however, beyond the scope of this paper.

During the 1980s in Pakistan, policymaking circles realized that nationalization had not been the panacea it was supposed to be: most PSEs, banks, and financial institutions (including DFIs) were perennially in dire financial straits. The public sector was effectively bankrupt with no reprieve in sight. Amid such a financial crunch, pressure for reforms came from the World Bank and IMF - not from within - to straighten out a nationalized system that was no longer sustainable and did not deliver. In other words, the government undertook reforms, structural adjustment, and privatization not because it was convinced to do so, but because it had no other option but to borrow from IFIs, given the impending insolvency and need for forex liquidity. Most PSEs, nationalized banks, and financial institutions were consequently slated for privatization. 
This reversal occurred on the same grand scale as nationalization. Once again, the industrial sector was turned upside down. The lynchpin of reforms was a revamped policy and incentive regime, along with PSE privatization, which peaked in the second half of the 1990s and went on till 2005. The process was long-drawn and more expensive than anticipated. The loss of net worth and operational costs of privatization were borne by the treasury, but were bundled with the low sale prices received on the auction block at the time of privatization compared to the actual market worth of PSE assets.

Privatization was carried too far and proved too expensive: many PSEs had been set up with money borrowed from the DFIs, which, in turn, had borrowed from the IFIs in hard currencies. The public sector was smothered, not because the PSEs or DFIs were irrelevant, but because their privatization provided a mechanism to sell off national assets at a pittance to favored buyers of the governing elite. Many PSEs were slated for privatization at throwaway prices to "investors" who had no stake in revitalizing or operating these enterprises. They bought such units only to strip down the plant and equipment, lay off employees, and sell the remaining bulk, making a fortune in the process. This is also why there were so many adherents of privatization at the time, while none were to be found in the 1970s. The same scenario is now being replayed in Pakistan's current phase of privatization.

In contrast, the East Asian economies kept their industrial transformation on the same track as before, but bolstered by massive FDI inflows and technology transfers. In setting up footloose industries, they further deepened their export-based industries, while their DFIs became stronger financial institutions than before. Even ailing DFIs were restructured: the government cleared their backlog of NPLs, replenished their equity base, and revitalized them. Korea and China also set up more DFIs, notably the Korea Development Bank, China Development Bank, and export-import banks, which enabled Korean and Chinese firms to operate overseas. Some of these firms are even active in Pakistan.

In financial terms, the East Asian DFIs continued to promote new industries and help diversify the industrial base, while the banking system took over financing large, well-established industrial firms that did not need state-supported funding. Such firms focused on manufactures for export, including high-tech items such as automobiles, household electronic equipment, and communications and IT equipment. Previously, they had lacked the capacity to produce at competitive prices 
for the international market. This transformation of the industrial sector echoed the success of advanced countries that had dominated the global production of high-tech manufactures until now.

These developments were buttressed by mounting foreign trade surpluses in East Asia's emerging economies. As the transformation progressed, it was followed by large foreign portfolio investment, capital market growth, the massive accumulation of forex reserves and, inevitably, enhanced exposure to exchange rate risks. This cut a deep swath later, when speculative investment in the stock market and real estate created a financial bubble that was liable to explode - as it did in the late 1990s. In the frenzy to invest, memories of the Japanese real estate bubble of 1991 had faded. When the financial crisis occurred, its swiftness and size left no room for escape and the East Asian "miracle" appeared to have become a debacle. Ultimately, the crisis needed massive joint intervention by central banks and governments to be contained. Within a few years, however, the East Asian economies had recovered.

India traversed more or less the same path of reforms in the 1990s, barring the financial crisis. It began by reforming the financial system, loosening the grip of the license raj over the private sector in general and the industrial sector in particular. However, the Indian DFIs did not close down: instead of vanishing, their client base had prospered to the point where the newly reformed banking system could take over clients' financing needs. These were infant industries that had matured and become strong enough to withstand competition in international markets. The DFIs moved on to finance new infants, such as recently established SMEs seeking a foothold first in the domestic market and - as the foreign trade regime opened up - then in the international market. While India's industrial sector had matured for this transformation, Pakistan continued to lurch between extremes, this time grappling with privatization amid questions about the role of the public sector if privatization were to reach such dimensions as it did in those turbulent years. We return to this later.

Both India and China have maintained a sizable network of DFIs since the 1990s and always actively promoted SME financing. India has three layers of DFIs. The top layer consists of flagship DFIs, including development banks - such as the Industrial Development Bank of India, IFCI Ltd, and the Industrial Investment Bank of India - and specialized financial institutions such as IFCI Venture Capital Funds and ICIC Venture Funds. The second layer comprises DFIs regulated by the Reserve Bank of India: these include the EXIM Bank, the National Bank 
for Agriculture and Rural Development, the Small Industries Development Bank of India, and the National Housing Bank. The third layer consists of state-owned DFIs, of which a fairly large number are active in various types of financing to promote economic growth, mostly local SMEs. India did not buy into the argument of financial repression or disband its DFIs, but - unlike Pakistan - it maintained financial discipline throughout, owing to its clients' business model.

The same applies to China, where a large number of DFIs, led by the China Development Bank, engaged in a range of financing activities to modernize the country's various sectors, bring industrialization to remote regions, and integrate them with the mainstream economy. This is a more pervasive role than simply providing finance for industrial investment.

In Pakistan, during the reforms, the National Development Finance Corporation and IDBI were closed down, as was Banker's Equity Ltd. PICIC was restructured as a commercial bank and the Agricultural Development Bank was resuscitated as the Zarai Taraqiati Bank Ltd (ZTBL). The SME Bank kept teetering on the brink, and despite efforts in the early 2000s could not be revived. The House Building Finance Corporation suffered severe loan losses and was nearly closed down, but survived with the help of considerable renewed financial support from the government. The Punjab Bank, a provincial DFI, went down a similar path, but survived with provincial support and was then resuscitated as a commercial bank.

\subsection{The Role of the Public Sector in Pakistan Revisited}

Until recently, most governments in Pakistan have generally shied away from demarcating roles for the public and private sectors, even during the halcyon days of nationalization. Many did not realize that it is easy to set up a heavy machinery complex in Taxila in the public sector and call it "industrialization" than to create an industrial society out of a traditionally rural society based on patterns of tribal sardari. The ensuing conflict between the perceived roles of the private sector versus the public sector stymied growth. Worse yet was the failure of many PSEs, as the government continued to bail them out through credit extended by the DFIs and banking system, which eventually proved insufficient.

During nationalization, the PSEs kept operating at unsustainable prices and exchange rates, financing each other through internally generated IOUs. Often, it took the government several years of repeated stabilization efforts to realize that, until the role of the PSEs was 
rationalized, budget and current account deficits would continue to emerge and reforms would not succeed. This failure to define the respective roles of the public and private sectors led to severe economic and financial problems, even though Pakistan underwent reforms and restructuring at an exorbitant cost.

Eventually, several PSEs were closed down, restructured, or privatized owing to the conditionalities attached to stabilization, debt relief, and restructuring funded by the IFIs; this generated severe opposition, compounding the chaos. Without a demarcation of roles, a policy and operational framework could not be designed, much less implemented, to ensure stability and growth. This did not support industrial transformation of the type that occurred among comparator countries, although Pakistan's economy became more diversified, reasonably open, and market-based after the reforms were over. The primacy of the public sector abated, but its legacy lingered for some time.

Privatization cannot be successful unless accompanied by major steps undertaken in parallel as part of the reforms. Foremost, as the owner of these financial institutions, the government had to restructure them before they were privatized. This involved (i) underwriting the costs of restructuring embedded in asset revaluation and employee severance, and (ii) cleaning up the balance sheet of deadweight NPLs and other assets of dubious value, partly through massive loan write-offs and provisioning for NPLs. In the process, state-owned financial institutions, banks, and DFIs together had to absorb the loan losses of the PSEs. The government also had to absorb the operational losses incurred.

Overall, the costs of privatization were staggering and were absorbed by the government and financed by borrowed funds. What these costs were is not known for certain. The resulting post-reforms structure was very different from the previous structure. Since the government did not have resources of its own to meet the costs of nationalization, it had borrowed cash loans in hard currencies from the IFIs for restructuring and reforms, thereby adding to the debt burden of the 1990s.

\subsection{The Post-Reforms Period}

In the early 2000s, as the newborn private corporate sector was being consolidated, setting up operations anew needed long-term industrial finance, but there were no surviving DFIs. The same situation is now transpiring in Pakistan amid reforms and exhortations to "do more." 
The dimensions of privatization can be gauged from changes in the ownership structure of PSEs, but we do not have data for the corporate sector, except for the banking and financial system. The existing data would likely reveal a major shift in the ownership of the banking system toward the private sector. The proportion of private share capital in the total share capital of the banking system was about one fifth at the start of the reforms in the 1990s. Currently, it is virtually all held by the private sector, excepting the National Bank of Pakistan, ZTBL, and a few others.

This was the magnitude of reversal, post-nationalization. The rub lies in the fact that, while the share of government ownership declined, its share of the use of total financial resources mobilized did not. This is evident from the public sector's share of banking system credit as well as government borrowings from the banking system.

A large volume of financial savings was channeled to the public sector through government borrowing from the banking system and money market operations. To arrive at an understanding of the total resources used by the public sector, we must combine the banking system credit to the public sector with its borrowings from money and capital markets, lodged as investments in banks, although these are loans to the government in the guise of investment. If we combine all these, we find that nearly 60 percent of the annual flows of financial resources - namely financial savings - were channeled to the public sector through the financial system, plus NSS operations (which are outside financial system flows), currency seigniorage, and inflation tax.

This has continued today. Consequently, the public sector is still able to garner a hefty share of the total financial resources generated in the country through the operations of the financial system, thus acquiring the underlying real resources. The crowding out of the private sector has been mitigated, but only in the sphere of banking credit, not in the context of resources at a macro-financial level.

This goes back to the issue of who generates and supplies financial resources, who eventually uses them, and how good is the transfer mechanism or financial intermediation in question. In all this, how much of these resources are available to promote the industrial sector is muddied, but the fact remains that the banking system is not known to provide term financing for the establishment of new industries. There may be scope for DFIs in Pakistan, but there are simply no DFIs left. 